\title{
Pengaruh Pupuk Kandang Plus Terhadap Pertumbuhan dan Produksi Jagung Manis di Purwodadi, Kabupaten Grobogan
}

\section{The Effect of Manure Plus on the Growth and Production of Sweet Corn in Purwodadi, Grobogan Regency}

\author{
Silfareda Aulia*, Dwi Retno Lukiwati, dan Eny Fuskhah \\ Department of Agroecotechnology, Faculty of Animal and Agricultural Science, Diponegoro University, Semarang, Indonesia \\ ${ }^{*}$ Corresponding author: silfaredaa@gmail.com
}

Received: July 27, 2021; Accepted: August 31, 2021; Published: October 31, 2021

\begin{abstract}
Manure plus is manure's nutrition improvement by the addition of organic $N$ from ( $L$. leucocephala) and nature $P$ from (rock phosphate). The aim of this research are to evaluate the effect of 'manure plus' on growth and production of sweet corn. The method used was Randomized Block Design with seven treatments and four replications. The treatments were P0 (ZA + TSP), P1 (Cattle manure + ZA + TSP), P2 (Goat manure + ZA + TSP), P3 (Poultry manure $+\mathrm{ZA}+\mathrm{TSP}$ ), P4 (Cattle manure + RP + + Leucaena leucocephala), P5 (Goat manure + RP+ Leucaena leucocephala), P6 (Poultry manure + RP + Leucaena leucocephala). $\mathrm{KCl}$ gave to all plots (150 kg K2O/ha). The parameters were plant height, leaf's number, cob length, cob diameter, sum of seed row, and production of sweet corn. Data subjected to analysis of variance and followed DMRT at $\alpha=5 \%$. The result showed that cob diameter and sum of seed row of P4 had no significantly different compared to P1, P5 had no significantly different compared to P2, P6 had no significantly different compared to P3. The leaf's number of P4 had no significantly different compared to P1, P5 had no significantly different compared to P2, whereas P3 had leaf's number more than P6. All treatments had no significant effect towards plant height, cob length and production of sweet corn. Based on the research, manure plus can be used to substitute the role of manure + ZA + TSP.
\end{abstract}

Key words: cattle manure; goat manure; poultry manure; rock phosphate

Cite this as: Aulia, S., Lukiwati, D. R., \& Fuskhah, E. (2021). Pengaruh pupuk kandang plus terhadap pertumbuhan dan produksi jagung manis di Purwodadi, Kabupaten Grobogan. Agrosains : Jurnal Penelitian Agronomi, 23(2), 99-104. DOI: http://dx.doi.org/10.20961/agsjpa.v23i2.53874

\section{PENDAHULUAN}

Jagung manis (Zea mays saccharata) merupakan salah satu komoditas yang banyak digemari di Indonesia karena nutrisinya cukup tinggi. Nutrisi yang terkandung pada jagung yaitu energi (96 cal), karbohidrat $(22,8 \mathrm{~g})$, protein $(3,5 \mathrm{~g})$, lemak $(1 \mathrm{~g})$, kalsium $(3 \mathrm{mg})$, dan beberapa kandungan vitamin lainnya (Suarni dan Yasin, 2011). Jagung manis memiliki nutrisi berupa karbohidrat dan beberapa vitamin, termasuk vitamin $\mathrm{E}$ (Feng et al., 2015). Selain itu jagung manis mengandung serat dan antioksidan yang bermanfaat untuk menjaga kesehatan. Jagung manis juga merupakan tanaman yang biasa digunakan sebagai uji respon terhadap pemupukan. Keunggulan tanaman jagung manis dibanding beras yaitu mengandung gizi yang lebih tinggi (Amelia et al., 2014) dan berumur pendek sekitar 60 - 70 hari (Sandiwantoro et al., 2017). Produksi jagung nasional tahun 2016 yaitu 23,58 juta ton, sedangkan tahun 2017 mencapai 28,92 juta ton (BPS, 2019). Jagung manis selain berfungsi untuk dikonsumsi juga dapat berguna sebagai pakan ternak. Bagian jagung yang biasa digunakan sebagai pakan ternak yaitu kelobot, bonggol dan jerami, sehingga seluruh hasil produksi jagung dapat dimanfaatkan tanpa meninggalkan limbah. Konsep tersebut dikenal dengan istilah Sistem Integrasi Tanaman-Ternak (SITT) yaitu hubungan timbal balik antara tanaman dengan hewan ternak (Ryschawy et al., 2017).

Budidaya jagung manis oleh petani di Indonesia secara umum masih menggunakan pupuk anorganik. Penambahan pupuk anorganik berpengaruh positif terhadap peningkatan jumlah daun jagung manis (Silalahi dan Karyawati, 2020).. Pupuk anorganik dapat menyediakan nutrisi yang mudah diserap oleh tanaman, akan tetapi tidak dapat meningkatkan kualitas tanah (Wirayuda dan Koesrihati, 2020). Pemupukan dengan pupuk anorganik secara berulang dengan dosis berlebih dapat merusak lingkungan. Pupuk anorganik dapat menyebabkan populasi mikroba tanah menurun (Bai et al., 2020). Upaya untuk mengatasi masalah tersebut yaitu mengganti pupuk anorganik dengan pupuk organik. Kandungan nutrisi pupuk organik beragam meskipun bersifat slow release. Dalam pupuk organik terdapat bahan organik yang mampu membenahi sifat fisik tanah antara lain menjaga stabilitas agregat, tekstur, kadar air, dan porositas tanah (Jambak et al., 2017). Salah satu contoh pupuk organik yang mudah ditemui dan digunakan yaitu pupuk kandang (pukan).

Terdapat berbagai macam pupuk kandang yang dapat dipakai untuk substitusi pupuk anorganik, diantaranya pupuk kandang sapi, kambing dan ayam. Kandungan unsur hara pupuk kandang yang beragam 
bergantung pada jenis ternak, makanan, umur dan kesehatan ternak (Purwati dan Islami, 2019). Pupuk kandang sapi lebih banyak tersedia, mudah ditemukan dan digunakan. Keunggulan pupuk kandang kambing yaitu berukuran lebih besar sehingga dapat memperbaki porositas dan aerasi tanah (Sanjaya et al., 2021). Unsur hara $\mathrm{N}$ yang terkandung pada pupuk kandang ayam relatif tinggi dibanding pupuk kandang lain karena pupuk padat tercampur dengan pupuk cair (urin) (Rahman et al., 2020).

Nutrisi pada pupuk kandang lebih rendah bila dibandingkan dengan pupuk anorganik. Rendahnya nutrisi pada pupuk kandang disebabkan oleh sifatnya yang lambat tersedia bagi tanaman (Putra et al., 2020). Nutrisi pada pupuk kandang perlu diubah menjadi bentuk anorganik dengan bantuan mikroba agar dapat diserap tanaman. Perlu dilakukan penambahan bahan organik lain untuk meningkatkan nutrisi pada pukan. Pupuk kandang dapat ditingkatkan nutrisinya dengan menambahkan $\mathrm{N}$ organik dan $\mathrm{P}$ alam. Pupuk kandang yang didekomposisi dengan $\mathrm{N}$ organik dan $\mathrm{P}$ alam dapat meningkatkan nutrisi pupuk. Kekurangan unsur hara $\mathrm{N}$ berpengaruh terhadap pertumbuhan tanaman terutama pada bagian daun dan batang (Hardian et al., 2021). Daun lamtoro merupakan salah satu contoh tanaman yang mengandung $\mathrm{N}$ organik. Kandungan nitrogen daun lamtoro terbilang cukup tinggi yaitu 3,84\% (Febriani et al., 2020), sedangkan batuan fosfat merupakan sumber $P$ organik yang nutrisinya cukup tinggi. Fosfat alam dapat digunakan untuk menggantikan pupuk kimia karena mengandung unsur makro dan mikro, serta tingkat efektivitasnya setara dengan TSP atau SP36 (Parhusip et al., 2020). Dekomposisi pupuk kandang + batuan fosfat menyebabkan peningkatan kandungan $P$ tersedia sehingga dapat meningkatkan kualitas pupuk (Lukiwati et al, 2018). vAplikasi pukan + batuan fosfat pada tanaman jagung dapat meningkatkan hasil sebesar $5-30 \%$ (Husnain et al., 2014).

Penambahan batuan fosfat pada pupuk kandang disarankan melalui proses dekomposisi. Dekomposisi merupakan proses kimia yang dapat meningkatkan kelarutan $P$ organik menjadi $P$ tersedia sehingga dapat diserap dan digunakan tanaman. Batuan fosfat dapat ditingkatkan kelarutannya melalui proses kimia oleh mikroba yang dapat mensistesis asam-asam organik sehingga $P$ dapat diserap tanaman (Flatian et al., 2018). Penambahan batuan fosfat berpengaruh positif pada parameter tinggi dan jumlah daun tanaman jagung (Fadilah dan Akbar, 2015). Nilai ideal rasio $\mathrm{C} / \mathrm{N}$ pada pupuk organik yaitu antara 15 - 20 (Meharbi, 2020). Pupuk organik dengan rasio $\mathrm{C} / \mathrm{N}$ terlalu tinggi menyebabkan aktivitas mikroorganisme tidak bekerja maksimal. Nilai rasio $\mathrm{C} / \mathrm{N}$ yang terlalu rendah menyebabkan hilangnya kelebihan nitrogen sebagai amonia sehingga tidak dapat diasimilasi oleh mikroorganisme (Balitbang Pertanian, 2011).Penelitian ini memiliki tujuan mengkaji pengaruh pukan plus terhadap pertumbuhan dan produksi jagung manis serta mengetahui kemampuan dalam mensubtitusi penggunaan pupuk anorganik.

\section{BAHAN DAN METODE}

Penelitian dilaksanakan pada Juli - Desember 2018 di lahan percobaan milik Dinas Pertanian Kabupaten
Grobogan dan Laboratorium Fisiologi dan Pemuliaan Tanaman Fakultas Peternakan dan Pertanian, Universitas Diponegoro, Semarang.

Bahan yang digunakan yaitu benih jagung manis varietas SD3 IPB, effective microorganism (EM4), pupuk kandang "pukan" (sapi, kambing, ayam), pupuk $\mathrm{P}$ alam (batuan fosfat/BP), pupuk $\mathrm{N}$ organik (daun lamtoro), pupuk anorganik (ZA, TSP dan $\mathrm{KCl}$ ), tetes tebu, dan berbagai bahan penunjang analisis kimia pupuk dan tanah. Peralatan yang digunakan yaitu cangkul, meteran, timbangan (gantung, duduk, analitik), jangka sorong, oven, label, alat tulis dan berbagai peralatan penunjang analisis kimia pupuk dan tanah.

Rancangan percobaan yang digunakan yaitu RAK Monofaktor dengan tujuh perlakuan dan empat ulangan sehingga didapatkan 28 unit petak percobaan. Perlakuan yang digunakan yaitu P0 (ZA + TSP), P1 (Pukan sapi + ZA + TSP), P2 (Pukan kambing + ZA + TSP), P3 (Pukan ayam + ZA + TSP), P4 (Pukan sapi + $\mathrm{BP}+$ daun lamtoro), P5 (Pukan kambing + BP + daun lamtoro), P6 (Pukan ayam + BP + daun lamtoro). Seluruh petak perlakuan diberi pupuk dasar $\mathrm{KCl} 150 \mathrm{~kg} \mathrm{~K}$ O/ha (Lukiwati et al., 2014). Penelitian diawali dengan pembuatan pupuk kandang (tanpa BP dan daun lamtoro) dan pupuk kandang plus (pupuk kandang yang diperkaya BP dan daun lamtoro). Dosis untuk pupuk BP yaitu $64,5 \mathrm{~kg} \mathrm{P} / \mathrm{ha}\left(150 \mathrm{~kg} \mathrm{P}_{2} \mathrm{O}_{5} / \mathrm{ha}\right.$ ), sedangkan dosis untuk daun lamtoro yaitu 5 ton/ha (200 kg N/ha) kemudian didekomposisikan selama 7 minggu. Setiap minggu pupuk diaduk agar homogen dan diberi tambahan EM4 dan tetes tebu. Dosis masing-masing pupuk kandang yaitu 20 ton/ha. Tahap selanjutnya pengolahan lahan dan pembuatan petak percobaan berukuran $2 \times 3,2 \mathrm{~m}$. Pukan plus diberikan tiga hari sebelum tanam, pupuk anorganik TSP dan $\mathrm{KCl}$ dengan dosis $150 \mathrm{~kg} / \mathrm{ha}$ diaplikasikan ketika tanam, dan pupuk ZA (200 kg N/ha) diberikan 7 hari setelah tanam secara tugal pada tiap lubang sesuai perlakuan. Penanaman dilakukan dengan membenamkan dua benih jagung pada setiap lubang dengan jarak 40 x $40 \mathrm{~cm}$ (populasi 40 tanaman/petak). Pengamatan dilakukan pada empat tanaman sampel yang terdapat ditengah petak. bedeng.

Perawatan tanaman jagung manis dilakukan dengan cara disiram tiap pagi dan sore hari serta dilakukan pembumbunan. Pengendalian hama dilakukan dengan pemberian insektisida, sedangkan pengendalian gulma dilakukan secara fisik (pencabutan). Panen dilakukan saat tanaman memasuki umur 72 HST. Parameter yang diamati yaitu tinggi tanaman, jumlah daun, panjang tongkol, diameter tongkol, jumlah baris biji per tongkol, serta produksi tongkol berkelobot. Parameter tinggi tanaman dan jumlah daun dihitung setiap seminggu sekali hingga panen, sedangkan panjang tongkol, diameter tongkol, jumlah baris biji per tongkol dan produksi tongkol berkelobot diukur setelah panen. Data yang didapatkan dianalisis menggunakan ANOVA, setelah itu diuji lanjut menggunakan DMRT (Duncan Multiple Range Test) pada taraf 5\% apabila terdapat pengaruh nyata antar perlakuan.

\section{HASIL DAN PEMBAHASAN \\ Pertumbuhan Tanaman Jagung Manis}

Berdasarkan hasil sidik ragam dapat diketahui bahwa perlakuan pemupukan tidak berpengaruh nyata 
terhadap tinggi tanaman, akan tetapi berpengaruh nyata terhadap jumlah daun $(\mathrm{P}<0,05)$. Berdasarkan Tabel 1 dapat diketahui perlakuan pupuk organik dan anorganik tidak berpengaruh terhadap tinggi tanaman, hal tersebut diduga disebabkan oleh pemberian pupuk dengan kandungan nutrisi yang sama pada seluruh perlakuan yang diujikan telah memenuhi kebutuhan untuk menunjang pertumbuhan tinggi tanaman. Rhezali dan Lahlali (2017) menyatakan bahwa tanaman jagung tidak dapat tumbuh optimal apabila kebutuhan unsur haranya tidak terpenuhi. Tinggi tanaman sebagian besar dipicu oleh ketersediaan hara nitrogen (N) dan fosfat (P). Menurut Hartanti et al., (2014) hara N berperan memicu pertumbuhan tanaman saat fase vegetatif. Hal tersebut didukung oleh pernyataan Sinuraya dan Melati (2019) bahwa unsur $\mathrm{N}$ berperan dalam pembelahan dan pemanjangan sel, sehingga mempengaruhi pertumbuhan tinggi tanaman. Menurut Polii dan Tumbelaka (2012) unsur $P$ berperan penting dalam memperkuat sistem perakaran dan batang tanaman.

Tabel 1. Tinggi dan Jumlah Daun Tanaman Jagung Manis terhadap Pupuk Kandang Plus

\begin{tabular}{ccc}
\hline Perlakuan & $\begin{array}{c}\text { Tinggi Tanaman } \\
(\mathrm{cm})\end{array}$ & $\begin{array}{c}\text { Jumlah Daun } \\
\text { (helai) }\end{array}$ \\
\hline P0 & 214,42 & $13,29^{\mathrm{a}}$ \\
P1 & 209,00 & $13,50^{\mathrm{a}}$ \\
P2 & 192,85 & $13,25^{\mathrm{a}}$ \\
P3 & 214,88 & $13,46^{\mathrm{a}}$ \\
P4 & 212,63 & $12,54^{\mathrm{ab}}$ \\
P5 & 215,71 & $12,58^{\mathrm{ab}}$ \\
P6 & 215,92 & $12,08^{\mathrm{b}}$ \\
\hline
\end{tabular}

Keterangan: Angka-angka yang diikuti oleh huruf yang berbeda menunjukkan pengaruh yang berbeda nyata antar perlakuan menurut DMRT pada taraf $\alpha=5 \%$. P0: ZA + TSP; $P 1$ : Pukan sapi + ZA + TSP; P2: Pukan kambing + ZA + TSP; P3: Pukan ayam + ZA + TSP; P4: Pukan sapi + BP + daun lamtoro; P5: Pukan kambing + BP + daun lamtoro; P6: Pukan ayam + $\mathrm{BP}+$ daun lamtoro.

Berdasarkan Tabel 1 dapat diketahui jumlah daun perlakuan P1, P2, P3, P4, dan P5 tidak berbeda nyata terhadap P0. Perlakuan P4 pukan sapi plus yang memiliki jumlah daun 12,54 helai tidak berbeda nyata terhadap P1 (13,50 helai). Perlakuan P5 dengan jumlah daun 12,58 helai tidak berbeda nyata terhadap perlakuan P2 (13,25 helai daun). Hasil yang tidak berbeda nyata tersebut diduga karena kandungan nutrisi pada pukan plus dan pukan + pupuk anorganik setara dan telah memenuhi kebutuhan tanaman. Perlakuan P6 dengan jumlah daun 12,08 helai nyata lebih rendah terhadap perlakuan P3 pukan ayam + ZA + TSP 13,46 helai. Hal tersebut disebabkan perlakuan pukan ayam plus terdiri dari bahan organik, sedangkan perlakuan P3 terdiri dari pupuk organik dengan penambahan pupuk anorganik. Menurut Silalahi dan Karyawati (2020), penambahan pupuk anorganik berpengaruh positif terhadap peningkatan jumlah daun jagung manis. Nutrisi pupuk anorganik lebih mudah diserap dan dimanfaatkan tanaman dibanding pupuk organik dengan nutrisi yang bersifat slow release. Wirayuda dan Koesriharti (2020) menyatakan bahwa pupuk anorganik dapat menyediakan nutrisi yang mudah diserap oleh tanaman, akan tetapi tidak dapat meningkatkan kualitas tanah.

Hal lain yang dapat mempengaruhi rendahnya jumlah daun perlakuan pukan ayam plus yaitu nilai rasio
$\mathrm{C} / \mathrm{N}$ yang sangat rendah $(6,48)$. Menurut Balitbang Pertanian (2011) nilai rasio $\mathrm{C} / \mathrm{N}$ yang sangat rendah menyebabkan hilangnya kandungan nitrogen berlebih sebagai amonia sehingga tidak dapat diasimilasi oleh mikroorganisme. Hilangnya $\mathrm{N}$ pada proses volatisasi tersebut menyebabkan kebutuhan nutrisi tanaman tidak terpenuhi, sedangkan nitrogen merupakan unsur penting yang mempengaruhi pertumbuhan daun. Rahmah et al. (2014) menyatakan bahwa nitrogen digunakan untuk menunjang pertumbuhan vegetatif tanaman termasuk dalam memicu perkembangan daun. Hal tersebut didukung oleh pernyataan Hardian et al., (2021) pertumbuhan daun dan batang tanaman dapat terhambat akibat kekurangan unsur hara $\mathrm{N}$.

Tabel 2. Panjang Tongkol, Diameter Tongkol dan Jumlah Baris Biji per Tongkol Jagung Manis terhadap Pupuk Kandang Plus

\begin{tabular}{cccc} 
Perlakuan & $\begin{array}{c}\text { Tinggi } \\
\text { Tanaman } \\
(\mathrm{cm})\end{array}$ & $\begin{array}{c}\text { Jumlah } \\
\text { Daun (helai) }\end{array}$ & $\begin{array}{c}\text { Jumlah } \\
\text { Baris } \\
\text { Biji per } \\
\text { Tongkol } \\
\text { (baris) }\end{array}$ \\
\hline P0 & 19,21 & $4,60^{\mathrm{ab}}$ & $15,50^{\mathrm{b}}$ \\
P1 & 18,81 & $4,80^{\mathrm{a}}$ & $16,00^{\mathrm{ab}}$ \\
P2 & 18,51 & $4,65^{\mathrm{ab}}$ & $16,25^{\mathrm{ab}}$ \\
P3 & 18,34 & $4,63^{\mathrm{ab}}$ & $15,94^{\mathrm{ab}}$ \\
P4 & 17,96 & $4,64^{\mathrm{ab}}$ & $17,19^{\mathrm{a}}$ \\
P5 & 18,36 & $4,49^{\mathrm{ab}}$ & $15,69^{\mathrm{b}}$ \\
P6 & 18,84 & $4,38^{\mathrm{b}}$ & $15,50^{\mathrm{b}}$ \\
\hline
\end{tabular}

Keterangan: Angka-angka yang diikuti oleh huruf yang berbeda menunjukkan pengaruh yang berbeda nyata antar perlakuan menurut DMRT pada taraf $\alpha=5 \%$. P0: ZA + TSP; P1: Pukan sapi + ZA + TSP; P2: Pukan kambing + ZA + TSP; P3: Pukan ayam + ZA + TSP; P4: Pukan sapi + BP + daun lamtoro; P5: Pukan kambing + BP + daun lamtoro; P6: Pukan ayam + $\mathrm{BP}+$ daun lamtoro.

Berdasarkan hasil analisis ragam, perlakuan pemupukan tidak berpengaruh terhadap parameter panjang tongkol, akan tetapi berpengaruh terhadap diameter tongkol dan jumlah baris biji per tongkol. Panjang tongkol jagung dipengaruhi oleh ketersediaan unsur hara P. Amiroh et al., (2020) menyatakan bahwa unsur fosfor diperlukan ketika tanaman memasuki fase generatif terutama saat terjadi pembentukan tongkol dan biji. Hal tersebut sesuai dengan pendapat Wahyudin et al., (2017) bahwa pemanjangan tongkol jagung terjadi karena terpenuhinya unsur $P$ tersedia yang dapat memicu peningkatan metabolisme tanaman yang berkaitan dengan pembelahan sel, diferensiasi, serta pemanjangan sel. Panjang tongkol selain dipengaruhi fosfor juga dipengaruhi faktor genetik. Hal tersebut didukung oleh penelitian Hilal dan Surahman (2015) yang menyatakan bahwa jagung manis varietas SD3 IPB memiliki rata-rata panjang tongkol 18,86 cm.

Berdasarkan Tabel 2 jumlah baris biji per tongkol menunjukkan hasil tidak berbeda nyata antara perlakuan pukan plus dan pupuk anorganik. Perlakuan P1 (16,00 baris) tidak berbeda nyata terhadap perlakuan $\mathrm{P} 4$ pukan sapi plus 17,19 baris. Perlakuan P2 (16,25 baris) tidak berbeda nyata terhadap perlakuan P5 pukan kambing plus 15,69 baris. Perlakuan P3 (15,94 baris) juga tidak berbeda nyata terhadap perlakuan P6 pukan ayam plus 15,50 baris, akan tetapi perlakuan P5 dan P6 lebih rendah dibanding perlakuan pukan sapi plus (P4). Unsur hara $\mathrm{N}$ dan $\mathrm{P}$ berpengaruh terhadap pembentukan 
jumlah baris biji. Nitrogen berguna dalam meningkatkan aktivitas metabolisme tanaman sehingga dapat meningkatkan jumlah baris biji. Sirajuddin dan Lasmini (2010) menyatakan bahwa kebutuhan $\mathrm{N}$ yang terpenuhi hingga saat tanaman mulai berbunga dapat mempercepat pembentukan baris biji per tongkol.

Unsur $P$ sangat dibutuhkan pada fase generatif tanaman jagung terutama saat masa pembentukan biji. Ramadana et al., (2020) menyatakan bahwa jumlah baris dipengaruhi oleh ketersediaan unsur $P$ yang dapat dimanfaatkan tanaman jagung. Hal tersebut didukung oleh Fitriatin et al., (2018), fosfor dibutuhkan dalam pembentukan buah pada tanaman jagung dan tersimpan dalam bentuk bulir. Jumlah baris biji per tongkol tidak berbeda nyata diduga karena nutrisi $\mathrm{N}$ dan $\mathrm{P}$ yang tersedia baik pada perlakuan pukan + pupuk organik maupun pukan + pupuk anorganik yang digunakan dapat memenuhi kebutuhan tanaman.

Berdasarkan Tabel 2, diameter tongkol perlakuan pukan plus dan perlakuan pupuk anorganik menunjukkan hasil tidak berbeda nyata. Perlakuan P4 pukan sapi plus dengan diameter tongkol $4,64 \mathrm{~cm}$ tidak berbeda nyata terhadap perlakuan P1 4,80 cm. Perlakuan P5 pukan kambing plus $(4,49 \mathrm{~cm})$ tidak berbeda nyata terhadap P2 dengan diameter tongkol $4,65 \mathrm{~cm}$. Perlakuan P6 pukan ayam plus $(4,38 \mathrm{~cm})$ juga tidak berbeda nyata terhadap P3 dengan diameter tongkol 4,63 cm. Pembentukan diameter tongkol dipengaruhi oleh ketersediaan nitrogen dan fosfor $(P)$. Su'ud dan Lestari (2018) menyatakan bahwa pemberian pupuk dengan kandungan nitrogen dapat menyebabkan peningkatan diameter tongkol jagung. Fosfor merupakan unsur makro yang dibutuhkan tanaman berkaitan dengan pembesaran diameter tongkol karena unsur $P$ berperan penting dalam pembentukan buah. Menurut Resman et al., (2018), fosfor berfungsi dalam pengisian biji dan pembesaran tongkol.

Diameter tongkol menunjukkan hasil tidak berbeda nyata diduga karena kebutuhan nutrisi tanaman telah terpenuhi, khususnya unsur fosfor. Menurut Ernita et al., (2017) kebutuhan fosfor yang tidak terpenuhi dapat menyebabkan diameter tongkol mengalami penyusutan. Hal tersebut didukung oleh Gupta (2018) bahwa kekurangan fosfor dapat menurunkan hasil produksi jagung. Diameter tongkol berkaitan erat dengan jumlah baris biji, sebab baris biji tumbuh melingkar sesuai dengan besarnya diameter tongkol. Hapsoh et al., (2020) menyatakan bahwa diameter tongkol berpengaruh terhadap pembentukan jumlah baris biji, semakin besar diameter maka semakin banyak pula baris biji yang dapat terbentuk.

\section{Produksi Tanaman Jagung Manis}

Berdasarkan Tabel 3, perlakuan pemupukan tidak berpengaruh nyata terhadap produksi. Hal tersebut diduga karena pukan plus dan pukan + ZA + TSP mengandung unsur hara yang setara dan telah memenuhi kebutuhan tanaman jagung manis, sehingga hasil produksinya yang tidak jauh berbeda. Menurut Bahri dan Purnomo, (2020), tercukupinya kebutuhan unsur hara tanaman akan berpengaruh pada peningkatan hasil produksi. Sesuai dengan pernyataan Wibowo et al., (2017), produksi jagung manis dapat ditingkatkan melalui proses pemupukan. Nutrisi pada pupuk organik sangat beragam baik makro maupun mikro, akan tetapi nutrisi tersebut hanya akan dilepaskan sedikit demi sedikit, sehingga tidak dapat dimanfaatkan tanaman secara optimal. Zega et al., (2021) menyatakan bahwa pupuk organik bersifat slow release, oleh karena itu tanaman berumur singkat kurang maksimal dalam memanfaatkan nutrisi pada pupuk. Oleh karena itu perlu dilakukan proses dekomposisi sehingga nutrisi pada pukan dapat diubah oleh bantuan mikroba menjadi tersedia dan dapat dimanfaatkan oleh tanaman.

Tabel 3. Produksi Tongkol Berkelobot Jagung Manis terhadap Pupuk Kandang Plus

\begin{tabular}{cc} 
Perlakuan & $\begin{array}{c}\text { Produksi Tongkol } \\
\text { Berkelobot (kg/petak) }\end{array}$ \\
\hline P0 & 14,60 \\
P1 & 13,83 \\
P2 & 13,15 \\
P3 & 12,85 \\
P4 & 12,03 \\
P5 & 12,69 \\
P6 & 12,48 \\
\hline
\end{tabular}

Keterangan: Angka-angka yang diikuti oleh huruf yang berbeda menunjukkan pengaruh yang berbeda nyata antar perlakuan menurut DMRT pada taraf $\alpha=5 \%$. P0: ZA + TSP; P1: Pukan sapi + ZA + TSP; P2: Pukan kambing + ZA + TSP; P3: Pukan ayam + ZA + TSP; P4: Pukan sapi + BP + daun lamtoro; P5: Pukan kambing + BP + daun lamtoro; P6: Pukan ayam + $\mathrm{BP}+$ daun lamtoro.

Pupuk NPK berperan penting dalam produksi tongkol jagung. Unsur $\mathrm{N}$ berperan dalam pembentukan fotosintat, zat-zat, serta senyawa-senyawa penting yang mendukung proses pembentukan tongkol. Unsur $P$ berperan dalam proses pembungaan, pembentukan buah dan pengisian biji. Hal tersebut sesuai dengan pernyataan Agustina dan Sudiarso (2020), fosfor merupakan sumber energi pada proses metabolisme tanaman yang berperan mentransfer hasil fotosintat ke dalam biji. Hal tersebut didukung oleh Sari dan Sudiarso (2019) menyatakan bahwa terpenuhinya kebutuhan $P$ menjadikan hasil fotosintesis lebih banyak dialirkan ke bagian tongkol sehingga meningkatkan ukuran tongkol. Kalium berfungsi memicu kinerja enzim dan pembentukan gula sehingga dapat mempercepat tanaman dalam memproduksi biji. Sesuai dengan Pradipta et al., (2014), unsur K berperan dalam meningkatkan kualitas dan bobot segar jagung manis.

\section{KESIMPULAN}

Pada parameter jumlah daun, perlakuan P4 dan P5 menghasilkan jumlah daun setara dengan perlakuan $\mathrm{P} 0$, P2 dan P3, sedangkan P6 (12,08 helai) menghasilkan jumlah daun lebih rendah dibanding perlakuan $P 0$ (13,29 helai) dan P3 (13,46 helai). Pada parameter diameter tongkol perlakuan P4, P5, dan P6 setara terhadap perlakuanp P0, P1, P2, dan P3. Pada parameter jumlah baris biji per tongkol perlakuan P4, P5 dan P6 setara terhadap perlakuan P1, P2, dan P3, akan tetapi P4 (17,19 baris) menghasilkan jumlah baris biji per tongkol lebih tinggi dibanding P0 (15,50 baris). Hasil yang setara antar perlakuan menunjukkan penggunaan pukan plus cukup efektif untuk budidaya jagung manis dan dapat digunakan untuk menggantikan peran pukan + pupuk anorganik. Seluruh perlakuan pemupukan tidak 
berpengaruh terhadap tinggi tanaman, panjang tongkol, dan produksi tongkol berkelobot jagung manis.

\section{DAFTAR PUSTAKA}

Agustina, Y. C. dan Sudiarso. 2020. Pengaruh pemberian pupuk kandang ayam dan Plant Growth Promoting Rhizobacteria (PGPR) pada pertumbuhan dan hasil tanaman jagung (Zea mays L.). J. Produksi Tanaman. $8(9)$ : 856 - 863.

Alfit, O. M. Samosir, T. Nainggolan, dan B. A. Sirait. 2020. Respon pertumbuhan dan produksi tanaman bawang merah (Allium ascalonicum L.) varietas bangkok terhadap aplikasi pupuk kandang sapi dan pupuk nitrogen. J. Agrotekda. 2 (2) : 13 - 24.

Amelia, J.R., S. Ma'arif, dan Y. Arkeman. 2014. Yoghurt susu jagung manis kacang hijau sebagai strategi inovasi produk alternatif pangn fungsional. J. Teknik Industri. 4 (3) : 172 - 183.

Amiroh, A., S. Z. Khumairoh, Istiqomah, dan Suharso. 2020. Kajian macam pupuk organik dan jarak tanam terhadap pertumbuhan dan produksi tanaman jagung (Zea mays L.). J. Agroradix. 3 (1) : 1 - 14.

Badan Penelitian dan Pengembangan Pertanian. 2011. Ragam Inovasi Pendukung Pertanian Daerah. Agroinovasi. 3: 1 - 11.

Bai,Y., Y. Chang, M. Hussain, B. Lu, J. Zang, X. Song, X. Lei, dan D. Pei. 2020. Soil chemical and microbiological Properties are changeed by long-tem chemical fertilizers that limit ecosystem functioning. J. Microorganism. 8 (694) : 1 - 22.

Ernita, E. J., H. Yetti, Ardian. 2017. Pengaruh pemberian limbah serasah jagung terhadap pertumbuhan dan produksi tanaman jagung manis (Zea mays Saccharata Sturt.). J. Online Mahasiswa Fakultas Pertanian Universitas Riau. 4 (2) : 1 - 15.

Fadilah dan K. Akbar. 2015. Pengaruh pemberian pupuk fosfat dan jarak tanam yang tepat terhadap pertumbuhan dan hasil tanaman jagung manis (Zea mays saccharata sturt). J. Penelitian AGROSAMUDRA. 2 (2) : 71 - 81.

Febriani, W. P., R. Y. Viza, dan L. Marlina. 2020. Pengaruh pemberian pupuk organik cair dari daun lamtoro (Leucaena leucocephala L.) terhadap pertumbuhan tanaman kangkung darat (Ipomea reptans Poir.) J. Pendidikan Biologi dan Biosains. 3 (1) : $10-18$.

Feng, F., Q. Wang, C. Liang, R. Yang, dan X. Li. 2015. Enhancement of tocopherols in sweet corn by marker-assisted bakrossing of ZmVTE4. J. Euphytica. $206: 513-521$.

Gupta, S., M. Kumari, H. Kumar, P. K. Varadwaj. 2017. Genome-wide analysis of miRNAs and tasi-RNAs in Zea mays in response to phosphate deficiency. 17 : $335-351$.

Hapsoh, I. R. Dini, dan A. Rahman. 2020. Uji formulasi pupuk hayati cair dengan penambahan Bacillus Cereus terhadap pertumbuhan dan hasil tanaman jagung manis (Zea mays saccharata Sturt). J. Agrotekma. 5 (1) : $31-41$.

Hardian, M., Basuni, dan M. Sahwan. 2021. Pengaruh kombinasi pupuk kandang ayam dan nitrogen terhadap pertumbuhan dan hasil tanaman jagung pada sistem budidaya jenuh air. J. Sains Mahasiswa Pertanian. 10 (1) : 1 - 14.

Hartanti, I., Hapsoh, dan S. Yoseva. 2014. Pengaruh pemberian pupuk hayati mikoriza dan rock phosphate terhadap pertumbuhan dan produksi tanaman jagung manis (Zea mays saccharata Sturt). J. Online Mahasiswa. 1 (1) : 1 - 14.

Hilal M. dan M. Surahman. 2015. Daya hasil dan kualitas jagung manis genotipe SD3 dengan empat varietas pembanding di Kabupaten Bandung. Bul. Agrohorti. 3 (3) : $316-322$.

Husnain, S. Rochayati, T. Sutriadi, A. Nassir, dan M. Sarwan. 2014. Improvement of soil fertility and crop production through direct application of phosphate rock on maize in Indonesia. Procedia Engineering. 83 : $336-343$.

Jambak, M. K. F. A., D. P. T. Baskoro, dan E. D. Wahjunie. 2017. Karakteristik sifat fisik tanah pada sistem pengolahan tanah konservasi (studi kasus: kebun percobaan Cikabayan). Bul. Tanah dan Lahan. 1 (1) : $44-50$.

Jati, G. K. dan N. Aini. 2018. Pengaruh berbagai dosis pupuk kandang kotoran ayam dan PGPR (plant growth promoting rhizobacteria) terhadap pertumbuhan dan hasil tanaman horenso (Spinacia oleracea L.). J. Produksi Tanaman. 6 (12) : 3014 3021.

Lukiwati, D. R., E. D. Purbajanti., dan R. I. Pujaningsih. 2014. Sweet corn production and nutritive value of stover with manure enriched with rock phosphate fertilizer and biodecomposer. J. of Agricultural Science and Technology A. 4 (10) : 839 - 842.

Lukiwati, D. R., F. Kusmiyati, dan B. Herwibawa. 2018. Effect of manure plus and inorganic fertilizer on maize production and nutrient uptake in Central Java Indonesia. Proceeding of the $5^{\text {th }}$ International Conference on Agriculture. 1 : $1-6$.

Merhabi, A. 2020. Utilization of compost: use and economical value of compost. J. Siplieria Sciences. 1 (2) : $14-19$.

Parhusip, D., N. Hutapea, G. Harahap, T. Handayani, A. Thohir, N. Harahap, dan S. M. Harahap. 2020. Peningkatan produksi tanaman jagung melalui pemberian pupuk an-organik fosfat alam. J. Agrica Ekstensia. 14 (2) : $113-118$.

Pradipta, R., K. Puji, dan B. Guritno. 2014. Pengaruh umur panen dan pemberian berbagai dosis pupuk kalium terhadap pertumbuhan dan kulitas jagung manis (Zea mays saccharata Sturt). J. Produksi Tanaman. 2 (7) : 529 - 599.

Putra, S. S., E. T. S. Putra, dan J. Widada. 2020. The eefects of types of manure and mycorrhizal applications on sandy soils on the growth and yield of curly red chili (Capsicum annum L.). J. Sustainable Agriculture Caraka Tani. 35 (2) : 258 - 267.

Purwati, R. D. dan T. Islami. 2019. Pengaruh jenis pupuk kandang terhadap pertumbuhan dan hasil tiga varietas jagung manis (Zea mays L. saccharata Sturt). J. Poduksi Tanaman. 7 (2) : 296 - 305. 
Rahmah, A., M. Izzati, dan S. Parman. 2014. Pengaruh pupuk organik cair berbahan dasar limbah sawi putih (Brassica chinensis L.) terhadap pertumbuhan tanaman jagung manis (Zea mays L. var. saccharata). Bul. Anatomi dan Fisiologi. 22 (1) : $65-$ 71.

Rahman, A., Subaedah, A. Muchdar, J. R. Ashar, dan Suriyanti. 2020. Pengaruh pemberian pupuk kandang ayam terhadap pertumbuhan bayam merah (Amaranthus tricilor L.). J. Agrotekmas. 1 (1) : 9 - 15.

Ramadana, M. A. I., A. Haitami, dan T Nopsagiarti. 2020. Respon pertumbuhan dan produksi tanaman jagung pulut (Zea mays ceratina Kulesh) terhadap pemberian pupuk petroganik dan pupuk TSP. J. Green Swarnadwipa. 9 (1) : 85 - 92.

Resman, A. Ansi, dan W. O. Harlis. 2018. Pengaruh pupuk organik cair dari sumber daya lokal terhadap hasil tanaman jagung dan sifat masam tanah.. J. Biowallacea. 5 (1) : $673-681$.

Rhezali, A. dan R. Lahlali. 2017. Nitrogen (N) mineral nutrition and imaging sensors for determining $N$ status and requirements of maize. J. Imaging. 3 (51) : $1-10$.

Ryschawy, J., G. Martin, M. Moraine, M. Duru, dan O. Therond. 2017. Designing crop-livestock integration at different levels: towards new agrocological models. J. Nutr. Cycl. Agroecosyst. $108: 5-20$.

Sandiwantoro, R. T., W. E. Murdiono, dan T. Islami. 2017. Pengaruh sistem olah tanah dan pemberian biochar pada pertumbuhan dan hasil tanaman jagung manis (Zea mays Saccharata Sturt.). J. Produksi Tanaman. 5 (10) : 1600 - 1607.

Sanjaya, P., N. Kurnia, K. Hendarto, dan F. Yelli. 2021. Pengaruh pupuk kandang dan pupuk hayati pada pertumbuhan dan produksi tanaman tomat (Lycopersicum esculenum Mill.) J. Agrotek Tropika. 9 (1) : $171-176$.
Silalahi, Y. H. dan A. S. Karyawati. 2020. Pengaruh pemberian pupuk urea dan pupuk kompos organik pada pertumbuhan dan hasil jagung manis (Zea mays saccharata L.). J. Produksi Tanaman. 8 (3) : $345-352$.

Sinuraya, B. A. dan M. Melati. 2019. Pengujian berbagai pupuk kandang kambing untuk pertumbuhan dan produksi jagung manis organik (Zea mays var. Saccharata Sturt). Bul. Agrohorti. 7 (1) : 47 - 52.

Sirajuddin, M dan S. A. Lasmini. 2010. Respon pertumbuhan dan hasil jagung manis (Zea mays saccharata) pada berbagai waktu pemberian pupuk nitrogen dan ketebalan mulsa jerami. J. Agroland. 17 (3) : $184-191$.

Suarni dan M. Yasin. 2011. Jagung sebagai sumber pangan fungsional. Iptek Tanaman Pangan. 6 (1) : 42 -56 .

Su'ud, M. dan D. A. Lestari. (2018). Respon pertumbuhan dan hasil tanaman jagung (Zea mays L.) terhadap konsentrasi dan interval waktu pemberian pupuk organik cair bonggol pisang. J. Agrotechbiz. 5 (2) : 37-52.

Wirayuda, B. dan Koesriharti. 2020. Pengaruh pemberian pupuk organik dan pupuk anorganik terhadap pertumbuhan dan hasil tanaman jagung manis (Zea mays L. var saccharata) . J. Produksi Tanaman. 8 (2) : 201 - 209.

Zega. D., D. Okalia, Maharani. 2021. Pengaruh pemberian berbagai pupuk kandang terhadap pertumbuhan dan produksi tanaman sawi (Brassica juncea L.) pada tanah ultisol. J. Green Swarnadwipa. $10(1): 103-108$. 